\title{
Tailored vs. Standard Curriculum and General English Achievement: A Study of Teachers' Views*
}

Currículo personalizado versus estándar y rendimiento en inglés general: un estudio de las opiniones de los profesores

Currículo personalizado versus padrão e desempenho em inglês geral: um estudo das opiniões dos professores

Bizhan Hekmatshoar Tabari

https://orcid.org/0000-0003-1393-64I7

Department of English Language, Tonekabon Branch, Islamic Azad University, Tonekabon, Iran

bizhan_hekmat@yahoo.com

Ramin Rahimy

https://orcid.org/0000-0002-0859-7812 Department of English Language, Tonekabon Branch, Islamic Azad University, Tonekabon, Iran rahimy49@yahoo.com

\footnotetext{
This paper is derived from the Doctoral dissertation, "An Investigation of the Effectiveness of Tailored vs. Standard Curriculum on Iranian University Students' Pre-Requisite General English Achievement across Gender: A Triangulation Approach," presented to the Islamic Azad University of Tonekabon. Available at: www.ris.iau.ac.ir
}

Received: 28/07/2020

Accepted by peers: 13/07/2021
Sent to peer review: $20 / 08 / 2020$

Approved: 06/09/2021

DOI: $10.5294 /$ laclil.2021.14.1.5

To reference this article (APA) / Para citar este artículo (APA) / Para citar este artigo (APA) Hekmatshoar-Tabari, B., \& Rahimy, R. (2021). Tailored vs. standard curriculum and general english achievement: A study of teachers' views. Latin American Journal of Content \& Language Integrated Learning, 14(1), 123-149. https://doi.org/10.5294/laclil.2021.14.1.5 
ABSTRACT. This study was conducted in two phases. The first one is the preliminary phase aimed at tailoring the standard curriculum based on learners' needs analysis. The second one is the main phase, intended to evaluate the tailored curriculum based on teachers' views. The participants in the preliminary phase of the study (tailoring the curriculum) were 346 non-native male and female undergraduate students who received the same Pre-Requisite General English course at their first semester in university. They were studying different majors, including Accounting, Architecture, Civil Engineering, Electrical Engineering, and Mechanical Engineering. The participants in the main phase (evaluation of the tailored curriculum by teachers) were 10 non-native male (7) and female (3) teachers who taught the Pre-Requisite General English course through the tailored curriculum. The findings of the study supported the hypothesis that the teachers have a positive attitude toward using the tailored curriculum in teaching the Pre-Requisite General English course. It seems that the implementation of this tailored program, which is based on learner-needs-analysis, can enhance the effectiveness of the English for General Purposes (EGP) course, compared to the standard one.

Keywords (Source: Unesco Thesaurus): English for General Purposes (EGP); needs analysis (NA); pre-requisite general English course; curriculum development; curriculum tailoring; curriculum evaluation.

RESUMEN. El presente estudio se realizó en dos etapas. La primera es la etapa preliminar que tiene como objetivo adaptar el currículo estándar a partir del análisis de necesidades de los aprendices. La segunda es la etapa principal, que busca evaluar el plan de estudios adaptado en función de las opiniones de los profesores. Los participantes de la etapa preliminar del estudio (adaptación del plan de estudios) fueron 346 estudiantes universitarios no nativos, hombres y mujeres, que tomaron el mismo curso prerrequisito de inglés general durante su primer semestre en la universidad. Eran estudiantes de diferentes carreras, incluyendo Contabilidad, Arquitectura, Ingeniería Civil, Ingeniería Eléctrica e Ingeniería Mecánica. Los participantes de la etapa principal (evaluación del plan de estudios personalizado por parte de los profesores) fueron 10 profesores no nativos, hombres (7) y mujeres (3), que impartieron el curso Prerrequisito de Inglés General a través del plan de estudios a personalizado. Los hallazgos del estudio apoyaron la hipótesis de que los profesores tienen una actitud positiva hacia el uso del plan de estudios adaptado al enseñar el curso prerrequisito de inglés general. Parece ser que la implementación de este programa personalizado, que se basa en el análisis de las necesidades del alumno, puede mejorar la eficacia del curso de inglés para fines generales (EGP), comparado con el curso estándar.

Palabras clave (Fuente: Tesauro de la Unesco): Inglés para fines generales (EGP); análisis de necesidades (NA); curso prerrequisito de inglés general; desarrollo curricular; adaptación curricular; evaluación curricular.

RESUMO. O presente estudo foi realizado em duas etapas. A primeira é a fase preliminar que visa adaptar o currículo padrão com base na análise das necessidades dos alunos. A segunda é a etapa principal, que busca avaliar o currículo adaptado com base na opinião dos professores. Os participantes da fase preliminar do estudo (adaptação do currículo) foram 346 estudantes universitários não-nativos, homens e mulheres, que fizeram o mesmo curso de pré-requisito geral de inglês durante o primeiro semestre na universidade. Eram alunos de diferentes carreiras, incluindo Contabilidade, Arquitetura, Engenharia Civil, Engenharia Elétrica e Engenharia Mecânica. Os participantes da etapa principal (avaliação do currículo personalizado pelos professores) foram 10 professores, homens (7) e mulheres (3) não nativos que ministraram o curso Pré-requisito de Inglês Geral por meio do currículo personalizado. Os resultados do estudo apoiaram a hipótese de que os professores têm uma atitude positiva em relação ao uso do currículo adaptado ao ensinar o curso Pré-requisito de Inglês Geral. Parece que a implementação deste programa personalizado, que se baseia na análise das necessidades do aluno, pode melhorar a eficácia do curso de Inglês para Fins Gerais (EGP), em comparação com o curso padrão.

Palavras-clave (Fonte: Tesauro da Unesco): Inglês para Fins Gerais (EGP); análise de necessidades (NA); curso de pré-requisito de inglês geral; desenvolvimento curricular; adaptação curricular; avaliação curricular. 


\section{Introduction}

In the higher education system of Iran, English as a Foreign Language (EFL) or English for General Purposes (EGP) is one of the main components of the curriculum and a compulsory element in bachelor's degree programs. All undergraduate students in every university must pass the EGP classes as a mandatory course subject. Before that, students with a low level of English language proficiency (based on their entrance exam results) are also required to pass a two-to-four credit Basic/Pre-requisite General English course during their freshman year. Following the EGP course, students must take one (or more) two-tofour credit English for Specific Purposes (ESP) course(s) later in their undergraduate program.

Unfortunately, studies have reported the ineffectiveness of the EGP courses in Iranian universities in providing the students with the necessary general language proficiency needed to enter the ESP courses (e.g., Atai \& Tahririan, 2003; Hayati, 2008; Khany \& Tarlani Aliabadi, 2016; Soodmand Afshar \& Movassagh, 2016; Zohrabi 2005). One of the very important reasons for such inefficiency is the lack of systematic learner-needs-analysis in designing the EGP courses compared to the ESP ones (e.g., Khansir, 2014; Moiinvarziri, 2014; Soodmand Afshar, \& Movassagh, 2016; Tavakoli \& Tavakol, 2018). According to Seedhouse's (1995) arguments, the main reason is "an erroneous belief that it is not possible to specify the needs of general English learners, and partly because of a lack of literature on the practicalities of analyzing needs data in the context of general English" (p. 59). He further sates that the leaners of the EGP course have a clear understanding of their needs and, thus, the result of their needs analysis can be employed effectively in designing the EGP course, its implementation, and evaluation.

Conducting needs analysis (NA) for the EGP courses is significant in terms of different important curricular aspects (e.g., Dooey, 2010; Gillett \& Hammond, 2011; Iwai et al., 1999; Nunan, 1988) and has its crucial part in creating tailor-made programs. As reported by Soodmand Afshar and Movassagh (2016), few studies have been conducted on needs analysis that tried to use its results into the EGP books or programs. As Tavakoli and Tavakol (2018) state, some studies have been 
recently run in order to design the EGP courses, based on the results of NA, but, at this time, there are no reports to let us know the results of such incorporation. In fact, curriculum evaluation as a fundamental component of curriculum design/development, which can show lapses, necessities and the parts that need further modifications, is generally neglected (Nation \& Macalister, 2011).

Based on Richards's (2001) conclusions, even after conducting the need analysis, curriculum designing, and curriculum implementation, the curriculum development process is still incomplete and the whole process requires evaluation. He states that curriculum evaluation intends to provide information about different aspects of a language so as to understand how successfully the program works and to make decisions for improvement. To put it differently, curriculum evaluation seeks answers to questions such as "whether the program responds to learners' needs, whether further teacher training is required for teachers' working in the program, or whether students are learning sufficiently from it" (Richards, 2001, p. 298).

Curriculum evaluation informs the effect of the curriculum on their users, including learners, teachers, and administrators (Richards, 2001; Tomlinson \& Masuhara, 2018). As Richards (2017) states, one aspect of language program that can be focused on evaluation is teachers' perceptions of the program. Moreover, a few EGP curriculum evaluation studies were conducted in Iran at the tertiary (university) level, and the majority of them have been concentrated on the highschool level.

Additionally, research has not focused much on the Pre-requisite General English course at Iranian universities, yet it can play a crucial role in bridging the language proficiency gap that first-term undergraduate students often have before entering the EGP course. "Unfortunately, although General English as a base for ESP is of great importance, studies have repeatedly concentrated on ESP" (Moiinvaziri, 2014, p. 58). The Pre-requisite General English course has even been eliminated from many university programs in Iran. 


\section{Review of Related Literature}

Language curriculum design/development have been conceptualized variously owing to different understandings of language teaching, both in terms of the nature of language itself and how it is learned (Richards, 2017; Richards \& Rodgers, 2014). In spite of those variations and controversies, most scholars recognize and emphasize NA and evaluation as two focal elements of such a process (Brown, 1995; Richards, 1990). For instance, as Richards and Schmidt (2002) hold, language teaching curriculum design includes:

a) the study of the purposes for which a learner needs a language (needs analysis), b) the setting of objectives and the development of a syllabus, teaching methods and materials, and c) the evaluation of the effects of these procedures on learners' language ability. (p.140)

NA and evaluation are two key components in the model proposed by Nation and Macalister (2010) (see Figure 1). As indicated in the figure, NA plays an important role in determining the goal and content of the course and the syllabus in the cycle. Evaluation is another essential component that can provide detailed information about every part of the cycle and reveal the lapses and necessities that require modifications.

\section{Needs analysis}

As Kleckova and Dalle (2018) state,

a well-designed language curriculum is a result of an elaborate process consisting of a needs and situation analysis followed by a careful planning of goals and learning outcomes. If course books are developed in alignment with such a curriculum, then there is a fitting relationship between the curriculum and the course books. Such teaching materials are often labeled as local or localized course books and can more directly enhance the development of learners' English language. They also support the curriculum and address the specific needs of the instructional context. (p. 2) 
Figure 1. A model of the parts of the curriculum design process

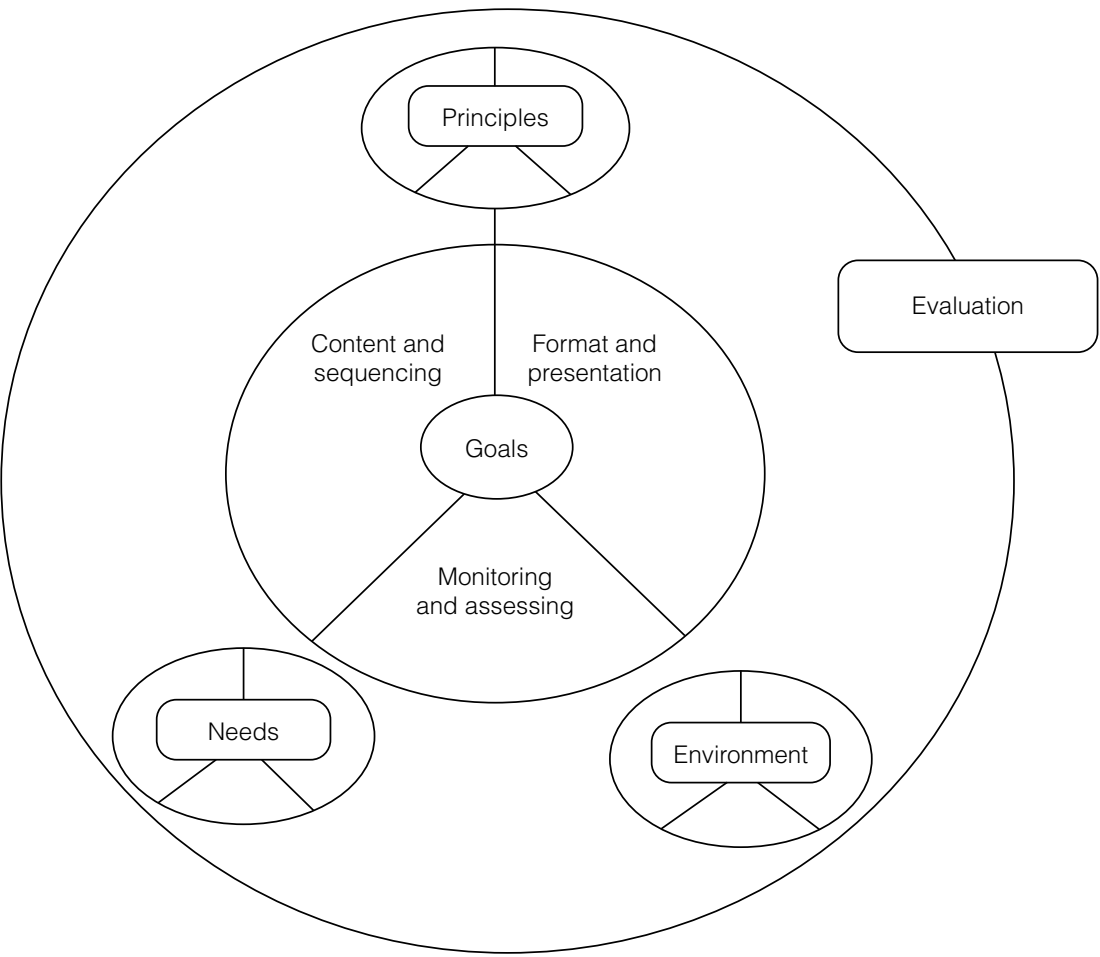

Source: Nation and Macalister (2010).

According to Johnson and Johnson (1999), NA has a crucial role in creating tailor-made programs:

The procedures associated with the analysis of needs offer the course designer a framework for the selection of language content according to the goals of particular learners and therefore the possibility of creating tailor-made programs, rather than starting with a ready-made syllabus that does not of itself discriminate between differing objectives. (p. 228)

Although studies have largely discussed the importance of needs analysis in language program and curriculum development regarding English as a Foreign Language (EFL) (e.g., Chaudron, et al., 2005; Iwai et al., 1999, etc.), ironically, most of them referred to lack of carefully done needs analysis as a major shortcoming. For instance, Nunan (2003) investigated the English curriculum of seven East Asian countries, including 
China, Hong Kong, Japan, Korea, Malaysia, Taiwan, and Vietnam. As a result, he noted some significant problems - an important one of which was regarding "a disjunction between curriculum rhetoric and pedagogical reality", (p. 589) which, as he states, needs to be resolved.

Studies conducted on ELT in tertiary level in Iran also indicate lack of congruence between curriculum objectives and classroom practices (Kiany, et al., 2011). According to Maftoon, et al. (2010), "curriculum developers have almost certainly neglected the students' needs and future demand" (p. 2). Some studies in Iran conducted needs analysis survey, but few have applied the result of students' and teachers' NA into the books or program (e.g., Behzadi \& Lashkarian, 2015; Gholami Mehrdad, 2012; Khansir, 2014).

According to Moiinvaziri (2014), research on Iranian students' needs analysis is almost new and most of them have been focused on ESP. As she states, there has not been any specific study regarding needs analysis of the General English course at university level in Iran, hence an in-depth study seems necessary. Tavakoli and Tavakol (2018) also believe that most studies have only listed some important problems and issues regarding English for Academic Purposes (EAP) at Iranian universities, while more systematic research needs to be done on their nature. According to them, one of those critical problems that require a systematic investigation is needs analysis.

\section{Evaluation}

However, as Richards (2001) states, after designing the curriculum, conducting the needs analysis and the actual implementation of the designed curriculum, the development is not totally over, as there are still lots of things to be considered. We need to deal with a number of questions: whether or not we achieved our goals, whether or not the stakeholders, such as teachers, students, administrators, and so on, are satisfied, which sort of classroom atmosphere was positively influential and the comparative strengths of the implemented curriculum over previous ones. In order to find an answer to all these questions, the whole process of our curriculum design needs to be evaluated. 
Based on the existing literature, most studies on EGP curriculum evaluation have been conducted at the primary and secondary levels, and a few have been carried out at tertiary (university) level. Dündar and Merç (2017) reviewed 86 studies on ELT curriculum evaluation around the world (e.g., Alwan, 2006; Burgos, 2012; Harris, 2010; Krekeller, 1993; Powell, 2008; Wang, 1996), which were mainly on the primary and secondary levels. Iran is not an exception, and the majority of studies concentrated on the high-school level (e.g., Ahmadi \& Derakhshan, 2015; Ahmadi Safa et al., 2017; Asadi, et al., 2016; Atai \& Mazlum, 2013; Ghanbari \& Ketabi, 2011; Jahangard, 2007; Nemati, 2009; Zohrabi \& Sabouri, 2012).

Curriculum evaluation has been defined as a systematic process of collecting and analyzing all relevant information in order to judge and assess the effectiveness of the curriculum and promote improvement (Brown, 1995; Marsh, 2004; Nichols et al., 2006). Evaluation is carried out through different instruments and from different sources. One of those important sources that is explored in this study to evaluate the tailored EGP curriculum is teachers' perceptions. In this section, several curriculum evaluation studies of the EGP courses at different universities in the world are reviewed, highlighting teachers' views as the main or a part of their evaluation process.

Nam (2005) conducted a study in South Korea that explored perceptions of both college students and teachers of English regarding their new communication-based English curriculum and instruction in a specific university-level English program. According to the results, although students have generally expressed negative opinions up to an extent, teachers have shown certain positive opinions about the effectiveness of the new curriculum. Moreover, the findings show that the current communication-based EFL curriculum seems not to comply with the students' desires, owing to several weaknesses of the curriculum itself and a few barriers already in the institutional system behind the curriculum.

Tunç (2010) aimed at evaluating the effectiveness of the Ankara University Preparatory School program through the perspectives of instructors and students in the 2008-2009 academic year. Findings of the study reveal that the program partially achieved its purpose, and some improvements in the physical conditions, content, material and assessment dimensions of the program were required. 
Mukundun and Nimehchisalem (2011) conducted a qualitative analysis of the content of the teaching courseware developed by the Curriculum Development Center of the Ministry of Education in 2003. This study aimed to determine the efficacy of the courseware from learning-teaching perspectives. Three English as a Second Language (ESL) instructors evaluated the program. As the results suggested, teachers mostly taught like a computer operator following a traditional linear approach, and learners were hardly engaged in any communication activity without the provided stimulus. The courseware also had a lopsided focus on language skills, and the time allocation prescribed by the courseware developers needed to be considerably increased.

Üstünlüoğlu et al. (2012) aimed at evaluating the effectiveness of the new teaching program, which was based on the Common European Framework (CEF) at the Preparatory Program of the School of Foreign Languages, Izmir University of Economics. Both new students and professors from different faculties participated in the study. According to the findings, there was a significant relationship between students' proficiency scores and the perception of their own competences, and a significant difference in perception of their own competences addressing different levels of preparatory program. Although faculty members stated that the program, in general, met the needs of the students, students had difficulty in practicing several tasks requiring higherorder thinking skills.

Mohamadi (2013) evaluated the general English program from the students' points of view and teacher analysis at Tabriz University. The result of the study indicated a mismatch between participants' needs, textbooks provided for the participants and the kind of teaching they received from their teachers. In fact, the general English course was not developed based on contemporary ELT principles.

Ínal et al. (2014) studied the effectiveness of the English preparatory curriculum at Çankaya University using Bloom's program evaluation model. Both new students and teachers participated in this study. According to the findings, both students and teachers were generally satisfied with the program. However, they thought that the learning outcomes of the curriculum did not match the requirements of their departments and the topics and themes of the curriculum were not related with students' departmental courses. Students also thought 
courses did not focus on speaking as much as they were supposed to, and they emphasized the need for more activities to stimulate speaking. Additionally, teachers complained about the intensity of the curriculum, the crowdedness of the classrooms and the lack of alternative assessment done in the curriculum.

Guo and Xu (2016) examined the English curriculum in terms of its workload burdened on teachers in China, stating that teachers complained about the workload of the curriculum and emphasizing the importance of using computer and advanced technologies in teaching and implementing the curriculum.

Arap (2016) explored student and teacher perceptions of the curriculum of the English preparatory schools from four different state universities. Findings revealed that the curriculum partially met the needs and expectations of the students and teachers. It was also found that students' perceptions regarding the curriculum were less positive compared to the perceptions of the teachers.

Bayram and Canaran (2019) evaluated the English Preparatory Program (EPP) at an English-medium foundation university in Turkey in terms of students and teachers' perceptions. According to the results, homework assignments, exams, and the program were the strength, while the extracurricular activities and online programs were considered the main weaknesses of the EPP. Furthermore, there was a statistically significant difference between students' and teachers' perceptions of the EPP. Finally, some improvements were suggested regarding program pacing, course books and complementary booklets, number of the portfolio assignments, and the picture description section of the Speaking Exam.

According to this, the present study first aimed at tailoring the standard curriculum for Pre-requisite General English Course based on learners' needs analysis and, then, evaluating the tailored curriculum in terms of the teachers' views. Hence, the following research question and hypothesis is posed for investigation: 


\section{Research Question}

RQ: Do teachers of the Pre-requisite General English course have a positive view on using the tailored curriculum in Iranian universities?

\section{Hypothesis of the Study}

$\mathrm{H}$ (Directional): Teachers of the Pre-requisite General English course have a positive view on using the tailored curriculum in Iranian universities.

\section{Methodology}

\section{The preliminary phase (tailoring the curriculum)}

\section{Participants}

This phase of the study was conducted with the participation of 346 male and female students who were taking the same Pre-Requisite General English course through the standard curriculum. They were all first-term undergraduate students between the ages of 18 to 28 , and their L1 was Persian. They were studying different majors (including Accounting, Law, Psychology, Architecture, Civil Engineering, Mechanical Engineering, and Electrical Engineering) at the Ayandegan Institute of Higher Education in Tonekabon, Iran.

\section{Design}

Because of the difficulty in samples availability, the convenience-sampling technique was used for selecting the participants. This part adopted survey research design in which an opinion questionnaire was used for data collection. In fact, a quantitative approach was applied in which the pre-requisite general English students' responses to multiple-choice items of a needs analysis questionnaire were explored. 


\section{Instrument}

A likert-type questionnaire designed by Mohamadi (2013) using the frameworks of scholars such as Flowerdew and Peacock (2001), Hutchinson and Waters (1987), Jordan (1997), and Robinson (1991) was used in the need analysis. This 28-item questionnaire consisted of five parts, including the learners' demographic information, target language needs, learners' present needs, learners' preferences and strategy use, and learners' learning needs, respectively. Since the respondents were not equipped with enough language proficiency to answer the questions without difficulty, the questions of the questionnaire were translated into Persian.

\section{Data collection and analysis}

To gather the required data, the NA questionnaires were distributed to the students who were taking Pre-Requisite General English course as part of the standard curriculum. Due to ethical issues in the research, they were informed by the researchers that their answers would be used confidentially just for the purposes of the research and their names and responses would be anonymous. After collecting the questionnaires, the data was analyzed quantitatively, using frequency analysis. Based on the results of the needs analysis questionnaire, the standard curriculum for the Pre-requisite General English course was tailored.

\section{The Main Phase (Evaluation of the Tailored Curriculum by Teachers)}

\section{Participants}

The main phase of the study was conducted with the participation of ten EFL teachers. All of them were non-native teachers of English who taught the pre-requisite general English course via both the standard and the tailored curriculum at the Ayandegan Institute of Higher Education in Tonekabon, Iran. The demographic information of the participants is summarized in Table 1 below: 
Table 1. Frequencies of teachers' demographic data

\begin{tabular}{|c|c|c|c|}
\hline Variable & Categories & Frequency & Percentage \\
\hline \multirow{2}{*}{ Gender } & Male & 7 & 70 \\
\hline & Female & 30 & 30 \\
\hline \multirow{5}{*}{ Age } & $30-40$ & 9 & 90 \\
\hline & $40-50$ & 0 & 0 \\
\hline & $50-60$ & 1 & 10 \\
\hline & $40-50$ & 0 & 0 \\
\hline & $50-60$ & 1 & 10 \\
\hline \multirow{3}{*}{ Education Degree } & M.A. & 6 & 60 \\
\hline & PhD Candidate & 4 & 40 \\
\hline & TEFL & 7 & 70 \\
\hline \multirow{3}{*}{ Field of Study } & Translation & 1 & 10 \\
\hline & Literature & 1 & 10 \\
\hline & Others & 1 & 10 \\
\hline \multirow{3}{*}{ Teaching Experience } & $0-10$ & 4 & 40 \\
\hline & $10-20$ & 6 & 60 \\
\hline & $20-30$ & 4 & 40 \\
\hline
\end{tabular}

Source: Own elaboration.

\section{Design}

This study starts with a survey research design and is followed by a quantitative approach in which an opinion questionnaire was used for data collection. In order to examine the teachers' views about using the tailored curriculum in teaching pre-requisite general English, the participants' responses to a Likert-type evaluation questionnaire were elicited.

\section{Instrument}

A researcher-made questionnaire was applied, consisting of 34 items on the Likert scale. Each statement had four possible responses: "strongly agree," "agree," “disagree," and "strongly disagree." The highest score (4) was on the scale "strongly disagree," which indicates a favorable attitude, 3 for "disagree," 2 for "agree" and 1 for "strongly agree." The reliability of this questionnaire was estimated using Cronbach's 
alpha $(\alpha=0.935)$. For the purpose of validity, the test was reviewed by two domain experts and minor revisions were made in order to make it ready for implementation.

\section{Data Collection and Analysis}

To collect the needed data, a Likert-type questionnaire was used, which intended to seek the teachers' views about using the tailored curriculum in teaching pre-requisite general English. The researchers distributed the questionnaires among the teachers and then, collected them. For the purpose of analysis, the data were analyzed quantitatively using frequency analysis.

\section{Results}

\section{The preliminary phase}

\section{Data analysis and findings}

According to the results (see Table 2), the majority (about 76\%) of students had enough motivation for learning English; in fact, they considered English as an important and necessary course in their studies. A large percentage of the learners (about 86\%) also thought that the present time allocation for this course needed to be increased. Additionally, about $63 \%$ of them believed that speaking skills needed to be emphasized in the overall English course. Unfortunately, this skill was not included in the course, and focus was usually on reading comprehension. Therefore, about half of the students (50\%), as they asserted, were good at reading and weak at speaking and listening. Thus, in addition to reading and writing, the participants' objective in the Pre-Requisite General English program should focus on speaking and listening skills, in order to minimize the gap between the participants' needs and the English course. A large number of the students (77\%) believed that the standard curriculum could not provide them with opportunities that made them able to extend what they have learnt beyond the classroom. Figure 2 shows the results of the leaners' questionnaire in terms of percentage. 
Table 2. Summary of the results of the learners' questionnaire

\begin{tabular}{|c|l|c|}
\hline $\mathbf{N}$ & \multicolumn{1}{|c|}{ Result } & Percentage \\
\hline 1 & $\begin{array}{l}\text { Well-motivated learners with the self-realization about } \\
\text { learning English as one of their needs }\end{array}$ & 76 \\
\hline 2 & $\begin{array}{l}\text { Emphasis of participants on the need to increase the } \\
\text { allocated time of the course }\end{array}$ & 66 \\
\hline 3 & $\begin{array}{l}\text { The majority's belief that speaking is the main objective of } \\
\text { learning English }\end{array}$ & 60 \\
\hline 4 & $\begin{array}{l}\text { The majority's experience in their strength in reading and } \\
\text { weaknesses in primary skills (listening and speaking) }\end{array}$ & 77 \\
\hline 5 & $\begin{array}{l}\text { Learners' demand for opportunities to extend what has } \\
\text { been learnt beyond the classroom }\end{array}$ & \\
\hline
\end{tabular}

Source: Own elaboration.

Figure 2. Results of the leaners' questionnaire in terms of percentage

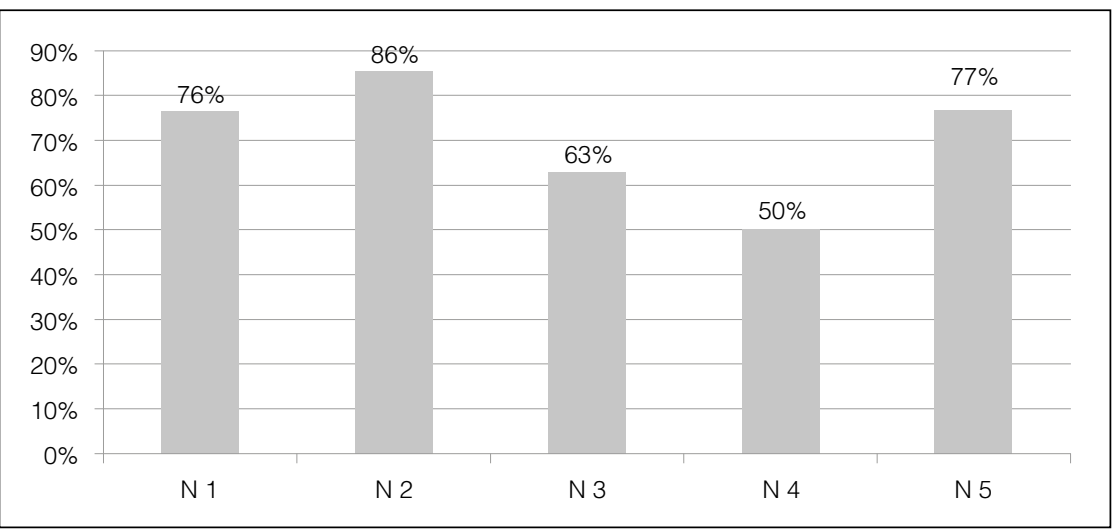

Source: Own elaboration.

Based on the results of the questionnaire used in the need analysis, the standard curriculum for pre-requisite general English course was tailored by:

1. including four language skills: listening, speaking, reading, and writing.

2. increasing time of exposing to teaching, via: 
a. expanding one normal three-credit university course (including 16 weeks of 3 hours) to three university terms.

b. dividing one weekly 3 hours-session into two 1.5 hours-sessions in a week.

3. prescribing a communicative, task-based textbook accompanied with a workbook, video book, CDs (audio) and VCDs (audio-visual).

4. providing all students in different classes of the same level with the opportunity to sit the same final exam in one exam session.

\section{The main phase}

\section{Data analysis and findings}

To answer the research question of this study, that is, to check if teachers had a positive view on using the tailored curriculum in teaching the pre-requisite general English course, the answers to the items of the questionnaire were calculated in terms of frequency and percentage. In order to have a better picture and interpretation of the respondents' answers to the items, the first two (strongly agree and agree) and the last two (disagree and strongly disagree) were added up together (see Table 3). Figure 3 shows teachers' attitude toward the tailored curriculum in terms of percentage.

Table 3. Teachers' attitude toward the tailored curriculum in terms of frequency $(F)$ and percentage $(P)$

\begin{tabular}{|c|l|c|c|c|c|}
\hline \multirow{2}{*}{$\mathbf{N}$} & \multicolumn{1}{|c|}{ Item } & \multicolumn{2}{|c|}{ SA+A } & \multicolumn{2}{|c|}{ D+SD } \\
\cline { 3 - 7 } & \multicolumn{1}{|c|}{$\mathbf{F}$} & $\mathbf{P}$ & $\mathbf{F}$ & $\mathbf{P}$ \\
\hline 1 & $\begin{array}{l}\text { The aims and objectives of the program } \\
\text { reflect the needs of learners. }\end{array}$ & 10 & 100 & 0 & 0 \\
\hline 2 & $\begin{array}{l}\text { The program enables the students to achieve } \\
\text { mastery in all language skills. }\end{array}$ & 9 & 90 & 1 & 10 \\
\hline 3 & $\begin{array}{l}\text { The program is based on the Communicative } \\
\text { Approach. }\end{array}$ & 8 & 80 & 2 & 20 \\
\hline 4 & $\begin{array}{l}\text { The program prepares students for life (real } \\
\text { language use). }\end{array}$ & 6 & 60 & 4 & 40 \\
\hline 5 & The textbook is accurate and up-to-date. & 9 & 90 & 1 & 10 \\
\hline
\end{tabular}




\begin{tabular}{|c|c|c|c|c|c|}
\hline \multirow{2}{*}{$\mathbf{N}$} & \multirow{2}{*}{ Item } & \multicolumn{2}{|c|}{ SA+A } & \multicolumn{2}{|c|}{ D+SD } \\
\hline & & $\mathbf{F}$ & $\mathbf{P}$ & $\mathbf{F}$ & $\mathbf{P}$ \\
\hline 6 & $\begin{array}{l}\text { The fact that the textbook (student book) is } \\
\text { accompanied by teachers' guide, workbook, } \\
\text { video book, CDs and VCDs has facilitated } \\
\text { teaching and learning. }\end{array}$ & 10 & 100 & 0 & 0 \\
\hline 7 & The textbook is organized effectively. & 10 & 100 & 0 & 0 \\
\hline 8 & $\begin{array}{l}\text { The textbook provides a balance of activities } \\
\text { (e.g., there is an even distribution of free vs. } \\
\text { controlled exercises and tasks that focus on } \\
\text { both fluent and accurate production). }\end{array}$ & 9 & 90 & 1 & 10 \\
\hline 9 & $\begin{array}{l}\text { The textbook activities encourage sufficient } \\
\text { communicative and meaningful practice. }\end{array}$ & 8 & 80 & 2 & 20 \\
\hline 10 & $\begin{array}{l}\text { The textbook activities incorporate individual, } \\
\text { pair and group work. }\end{array}$ & 8 & 80 & 2 & 20 \\
\hline 11 & $\begin{array}{l}\text { The grammar points and vocabulary items } \\
\text { are introduced in motivating and realistic } \\
\text { contexts. }\end{array}$ & 8 & 80 & 2 & 20 \\
\hline 12 & $\begin{array}{l}\text { The tasks are conducive to the internalization } \\
\text { of newly introduced language. }\end{array}$ & 8 & 80 & 2 & 20 \\
\hline 13 & $\begin{array}{l}\text { The textbook activities can be modified or } \\
\text { supplemented easily. }\end{array}$ & 8 & 80 & 2 & 20 \\
\hline 14 & $\begin{array}{l}\text { The materials include, and focus on, the } \\
\text { skills that the students need to practice. }\end{array}$ & 8 & 80 & 2 & 20 \\
\hline 15 & $\begin{array}{l}\text { The materials provide an appropriate } \\
\text { balance of the four language skills. }\end{array}$ & 9 & 90 & 1 & 10 \\
\hline 16 & $\begin{array}{l}\text { The textbook pay attention to sub-skills (i.e., } \\
\text { listening for gist, note-taking, skimming for } \\
\text { information, etc.). }\end{array}$ & 9 & 90 & 1 & 10 \\
\hline 17 & $\begin{array}{l}\text { The textbook highlights and practices natural } \\
\text { pronunciation (i.e., stress and intonation). }\end{array}$ & 8 & 80 & 2 & 20 \\
\hline 18 & $\begin{array}{l}\text { The practice of individual skills is integrated } \\
\text { into the practice of other skills. }\end{array}$ & 9 & 90 & 1 & 10 \\
\hline 19 & $\begin{array}{l}\text { The language used in the textbook is } \\
\text { authentic (i.e., like real-life English). }\end{array}$ & 7 & 70 & 3 & 30 \\
\hline 20 & $\begin{array}{l}\text { The language used is at the right level for my } \\
\text { students' current English ability. }\end{array}$ & 8 & 80 & 2 & 20 \\
\hline 21 & $\begin{array}{l}\text { The progression of grammar points and } \\
\text { vocabulary items are appropriate. }\end{array}$ & 9 & 90 & 1 & 10 \\
\hline 22 & $\begin{array}{l}\text { The grammar points are presented with brief } \\
\text { and easy examples and explanations. }\end{array}$ & 10 & 100 & 0 & 0 \\
\hline
\end{tabular}




\begin{tabular}{|c|c|c|c|c|c|}
\hline \multirow{2}{*}{$\mathbf{N}$} & \multirow{2}{*}{ Item } & \multicolumn{2}{|c|}{$\mathrm{SA}+\mathrm{A}$} & \multicolumn{2}{|c|}{$\mathrm{D}+\mathrm{SD}$} \\
\hline & & $F$ & $P$ & $F$ & $P$ \\
\hline 23 & $\begin{array}{l}\text { The language functions exemplify English } \\
\text { that my students will be likely to use. }\end{array}$ & 10 & 100 & 0 & 0 \\
\hline 24 & $\begin{array}{l}\text { The subject and content of the textbook is } \\
\text { relevant to my students' needs as English } \\
\text { language learners. }\end{array}$ & 9 & 90 & 1 & 10 \\
\hline 25 & $\begin{array}{l}\text { The subject and content of the textbook is } \\
\text { generally realistic. }\end{array}$ & 8 & 80 & 2 & 20 \\
\hline 26 & $\begin{array}{l}\text { The subject and content of the textbook are } \\
\text { interesting, challenging, and motivating. }\end{array}$ & 8 & 80 & 2 & 20 \\
\hline 27 & $\begin{array}{l}\text { There is sufficient variety in the subject and } \\
\text { content of the textbook. }\end{array}$ & 9 & 90 & 1 & 10 \\
\hline 28 & $\begin{array}{l}\text { The materials are not culturally biased and } \\
\text { they do not portray any negative stereotypes. }\end{array}$ & 9 & 90 & 1 & 10 \\
\hline 29 & $\begin{array}{l}\text { The textbook is appropriate for language- } \\
\text { learning aims of Pre-Requisite General } \\
\text { English course students at university. }\end{array}$ & 10 & 100 & 0 & 0 \\
\hline 30 & $\begin{array}{l}\text { The medium of instruction in the class is } \\
\text { English and the students interact in the class } \\
\text { in English. }\end{array}$ & 6 & 60 & 4 & 40 \\
\hline 31 & $\begin{array}{l}\text { The textbook raises my students' interest in } \\
\text { further English language study. }\end{array}$ & 7 & 70 & 3 & 30 \\
\hline 32 & $\begin{array}{l}\text { Extension of the number of hours of the Pre- } \\
\text { Requisite General English program. }\end{array}$ & 10 & 100 & 0 & 0 \\
\hline 33 & $\begin{array}{l}\text { Giving all students in different classes of the } \\
\text { same level the same Final Exam in one exam } \\
\text { session improves evaluation. }\end{array}$ & 10 & 100 & 0 & 0 \\
\hline 34 & $\begin{array}{l}\text { Equipping classes with facilities such as } \\
\text { computer, video projection system, etc., } \\
\text { enhances students' language learning. }\end{array}$ & 10 & 100 & 0 & 0 \\
\hline
\end{tabular}

Source: Own elaboration. 
Figure 3. Teachers' attitude toward the tailored curriculum in terms of percentage

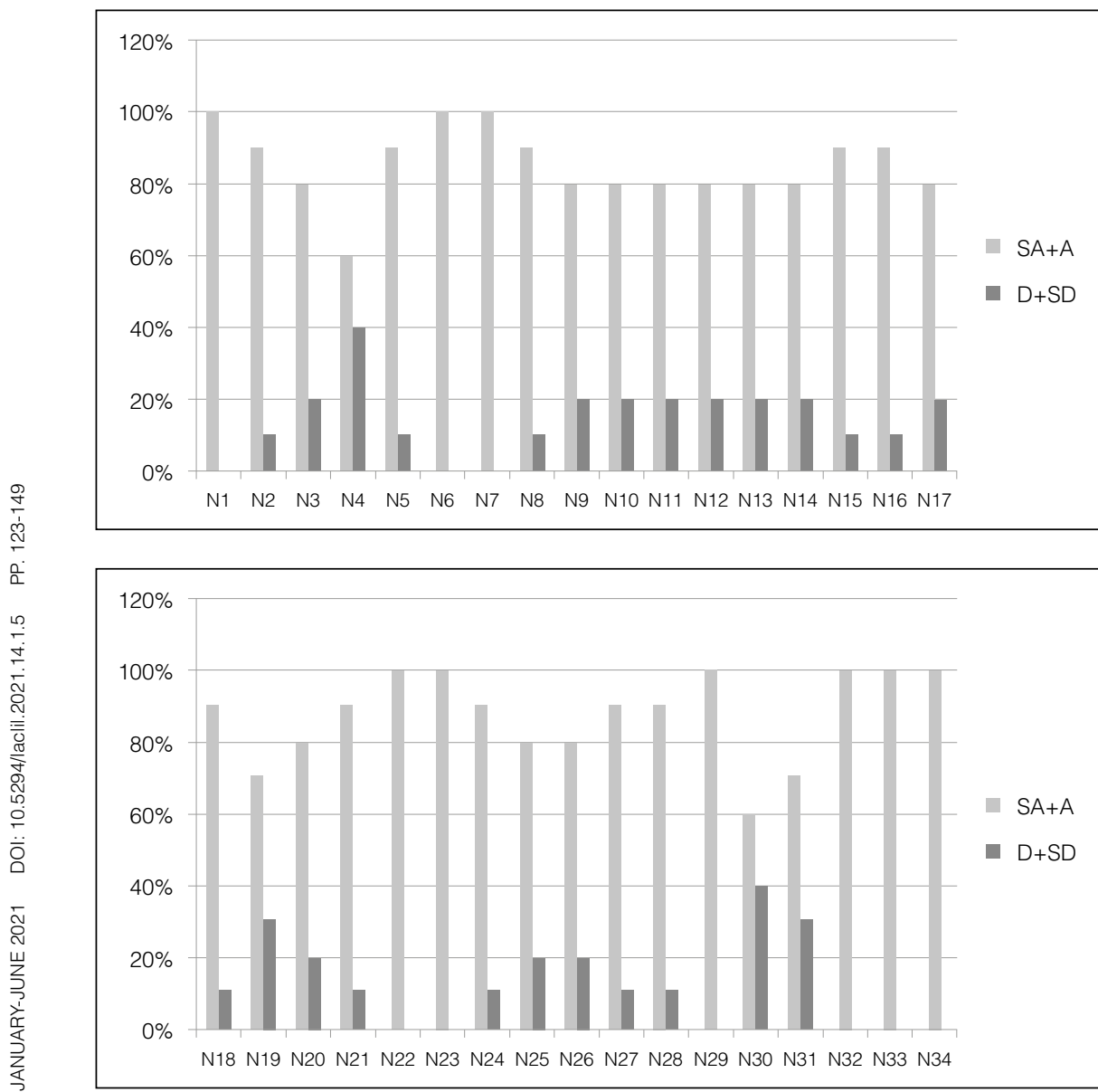

Source: Own elaboration.

The mean score of the number of respondent teachers who agreed with the items of the questionnaire was 8.64, and the standard deviation was 1.1. The neutral point was 4.32, which was half of the mean score. As the standard deviation was less than the mean score over the neutral point, it can be concluded that teachers had a positive attitude toward using the tailored curriculum in teaching the Pre-Requisite General English course. Thus, the hypothesis is supported.

As shown in the figure above, 100\% of the teachers agreed with 9 items out of 34 items of the questionnaire. These items were 1, 6, 7, 22, $23,29,32,33$, and 34 , which are discussed as follows: 
Based on the teachers' answer to item number 1, i.e., the aims and objectives of the program reflect the needs of learners, it seems that the tailored curriculum is based on a carefully conducted needs analysis, which is considered as one of the most important factors regarding an appropriate curriculum.

One hundred percent of teachers agreed with item 29. This indicates that a suitable textbook was chosen - a textbook apt for the language-learning aims of Pre-Requisite General English course students in university through appropriate need analysis.

Items $6,7,22$, and 23 were textbook related. Item 6 focused on choosing a suitable textbook (student book) accompanied by its teachers' guide, workbook, video book, CDs, and VCDs, and item 7 was concerned with a well-organized textbook. Items 22 and 23 were related to presentation of grammar points and language functions emphasizing on easy, useful explanation, and exemplification.

Respondents' answers to items 32, 33, and 34 highlight the effective changes to traditional curriculum. In other words, the extension of the number of hours of the Pre-Requisite General English program, a unified evaluation, and enhancement of educational facilities, which have led to sound learning.

Although the results show teachers' high level of agreement $(86.47 \%)$ with the tailored curriculum, there were few items that were not highly agreed upon comparing them with the other items. For instance, $40 \%$ of the teachers did not agree with items 6 and 30. Based on the answers to item $4,40 \%$ of the teachers believe that the program has not prepared students for life (real language use). This may happen because of students' lack of interest in learning English and unsuccessful learning experience that they had before entering university. Thus, many of them prefer only to pass these courses without trouble.

According to $40 \%$ of the teachers, the medium of instruction in the class is not English, and the students cannot interact in the class in English. One reason may arise from the students' resistance to English as a medium of instruction because they say they are unable to understand it because their education prior to the university level had been Persian (their mother tongue). In addition to this, another reason may be the students' lack of adequate listening and speaking ability with which they enter the program and their lack of interest in learning English. 


\section{Discussion and Conclusion}

The findings of the preliminary phase of this study, i.e., learnerneeds-analysis, have revealed that the majority of learners believe that the most important skill is speaking, and oral communication is their main objective. Unfortunately, this objective is paradoxically neglected in the standard program. This is in line with Mohamadi's (2013) study, which reported speaking as the most crucial skill, but which is missing in the curriculum. Behzadi and Lashkarian (2015) have also reported similar findings in which speaking is the most necessary skill in the EGP course. However, Gholami Mehrdad (2012) and Moiinvaziri's (2014) study contrasts with the present study in that, reading is considered as the most important language skill, though listening and speaking are pointed out as the learners' most problematic skills.

Based on the findings of the learners' needs analysis, the tailored curriculum was designed with an attempt to incorporate NA results in developing a curriculum that fit better to the EGP students' needs. After implementing the tailored curriculum, it was evaluated based on the teachers' views. The findings of this part revealed that the teachers had a positive attitude toward using the tailored curriculum in the Pre-Requisite General English course. As it can be inferred from the results, the teachers mostly agreed with the fact that the tailored curriculum was created, based on a carefully conducted needs analysis according to which a suitable textbook was chosen matching well with the language-learning aims of Pre-Requisite General English course students at the university. In addition, they highly agreed with the effective changes processed in the traditional curriculum, extension of the number of hours of Pre-Requisite General English program, a unified evaluation and enhancement of educational facilities, have led to sound learning. It seems that the implementation of this tailored program, which was based on the needs analysis, could enhance effectiveness of the EGP course compared to the standard one, whose inefficiency has been reported in many studies owing to lack of carefully conducted needs analysis as one of the major problems (e.g., Khansir, 2014; Mohamadi, 2013; Moiinvarziri, 2014; Soodmand Afshar \& Movassagh, 2016; Tavakoli \& Tavakol, 2018). 
Because the findings of this study cannot be generalized to all the universities in the country, a similar study is suggested for the Pre-Requisite General English course in other universities. This sort of studies can generally be helpful to enhance the effectiveness of EGP courses at universities, emphasizing the need for this sort of needs analysis and evaluation studies for curriculum improvement. Such studies would be useful for theorizers, policy makers, language planners, curriculum designers, textbook developers in the Iranian education system to make necessary changes making curriculum learner-centered well.

As the final remarks, it is suggested to make the same study more comprehensive than this by extending the evaluation to consider learners' and administrators' ideas, as well, without limiting it only to those of teachers.

\section{References}

Ahmadi, A., \& Derakhshan, A. (2015). An evaluation of the Iranian junior high school English textbooks "Prospect 1" and its old version "Right Path to English 1" from teachers' perceptions. International Journal of English Language and Literature Studies, 4(1), 37-48. DOI: https://doi. org/10.18488/journal.23/2015.4.1/23.1.37.48

Ahmadi-Safa, M., Ghonchepoor, A., Malek Mohamadi, R., Seifi, Z., \& Zekrati, S. (2017). Prospect II: A textbook evaluation study based on EFL teachers' perspective. Journal of Language Research (JLR), 9(24), 7-32. DOI: https://doi.org/10.22051/JLR.2016.2437

Alwan, F. H. (2006). An analysis of English language teachers' perceptions of curriculum change in the United Arab Emirates (Unpublished Doctoral dissertation). University of Exeter, Exeter.

Arap, B. (2016). An investigation into the implementation of English preparatory programs at tertiary level in Turkey (Doctoral dissertation). Çukurova Üniversitesi, Adana.

Asadi, M., Kiany. G. R., Akbari, R., \& Ghafar Samar, R. (2016). Program evaluation of the new English textbook (Prospect1).Theory and Practice in Language Studies, 6(2), 291-301. DOI: https://doi.org/10.17507/ tpls.0602.10 
Atai, M. R., \& Mazlum, F. (2013). English language teaching curriculum in Iran: Planning and practice. The Curriculum Journal, 24(3), 389-411. DOI: https://doi.org/10.17263/jlls.547606

Atai, M. R., \& Tahririan, M. H. (2003). Assessment of the ESP status in the current Iranian higher education system. LSP 2000, communication, culture and knowledge. University of Surrey.

Bayram, Í., \& Canaran, Ö. (2019). Evaluation of an English preparatory program at a Turkish Foundation University. Journal of Language and Linguistic Studies, 15(1), 48-69. DOI: https://doi.org/10.17263/jlls.547606

Behzadi, A., \& Lashkarian, A. (2015). Iranian undergraduate students' needs in English courses for general and specific purposes. International Journal of English and Education, 4(3), 67-80.

Brown, J. R. (1995). The elements of language curriculum: A systematic approach to program development. Heinle \& Heinle.

Burgos, S. (2012). Behind classroom doors: Consistency between policy and practice in the English as a second language classroom (Unpublished Doctoral dissertation). Universidad Del Turabo, Puerto Rico.

Chaudron, C., Doughty, C., Kim, Y., Kong, D. Lee, J., Lee, Y., Long, M., Rivers, R., \& Urano, K. (2005). A task-based needs analysis of a tertiary Korean as a foreign language program. In M. Long. (Ed.), Second language needs analysis (pp. 225-261). Cambridge University. DOI: https://doi.org/10.1017/CBO9780511667299.009

Dooey, P. (2010). Students' perspectives of an EAP pathway program. Journal of English for Academic Purposes, 9, 184-197. DOI: https://doi. org/10.1016/j.jeap.2010.02.013

Dündar, E., \& Merç, A. (2017). A critical review of research on curriculum development and evaluation in ELT. European Journal of Foreign Language Teaching, 2(1), 136-168. DOI: https://doi.org/10.5281/zenodo. 437574

Flowerdew, J., \& Peacock, M. (2001). Research perspective for EAP. Cambridge University Press.

Ghanbari, B., \& Ketabi, S. (2011). Practicing a change in an Iranian EFL curriculum: From ivory tower to reality. The Iranian EFL Journal, 7(6), 268-282.

Gholami Mehrdad, A. (2012). A subjective needs assessment of EGP students. Procedia-Social and Behavioral Sciences, 31, 546-554. DOI: https:// doi.org/10.1016/j.sbspro.2011.12.101 
Gillett, A. J., \& Hammond, A. C. (2011). Pre-Master's course design: What can we learn from assessment? In S. Etherington (Ed.), English for specific academic purposes (pp. 95-100). Reading: Garnet Education.

Guo, Z., \& Xu, L. (2016). Study on the integration mode of computer network technology and college English curriculum. International Journal of Emerging Technologies in Learning, 11(8), 40-46. DOI: https://doi. org/10.3991/ijet.v11i08.6046

Harris, L. S. (2010). A case study of the English second language programs of a North Carolina school district (Unpublished Doctoral dissertation). The University of North Carolina, Charlotte.

Hayati, A. M. (2008). Teaching English for special purposes in Iran problems and suggestions. Arts and Humanities in Higher Education, 7(2), 149-164. DOI: https://doi.org/10.1177/1474022208088645

Hutchinson, T., \& Waters, A. (1987). English for specific purposes: A learning-centered approach. Cambridge University Press.

Iwai, T., Kondo, K., Lim, D. S. J., Ray, G. E., Shimizu, H., \& Brown, J. D. (1999). Japanese language needs assessment 1998-1999 (NFLRC Net Work \#13) [HTML document]. Honolulu: University of Hawai'i, Second Language Teaching \& Curriculum Center. http://www.nflrc.hawaii. edu/NetWorks/

Ínal, B., \& Aksoy, E. (2014). Evaluation of the curriculum of English preparatory classes at Çankaya University. Journal of Education and Training Research, 3(3), 85-98.

Jahangard, A. (2007). Evaluation of EFL materials taught at Iranian public high schools. Asian EFL Journal 9(2), 130-150.

Johnson, K., \& Johnson, H. (1999). Encyclopedic dictionary of applied linguistics: A handbook for language teaching. Blackwell Publishing Ltd.

Jordan, P. R. (1997). English for academic purposes. Cambridge University Press.

Khansir, A. K. (2014). Needs analysis and General English Language. International Journal of Language Learning and Applied Linguistics World (IJLLALW), 7(2), 161-174.

Khany, R., \& Tarlani-Aliabadi, H. (2016). Studying power relations in an academic setting: Teachers' and Students' perceptions of EAP classes in Iran. Journal of English for Academic Purposes, 21, 72-85. DOI: https:// doi.org/10.1016/j.jeap.2015.12.002

Kiany, G. R., Mahdavy, B., \& Ghafar Samar, R. (2011). "Towards a Harmonized Foreign Language Education in Iran: National Policies and 
English Achievement." Literacy Information and Computer Education Journal, 2, 462-469.

Kleckova, G., \& Dalle, T. (2018). Working with a course book and the curriculum. The TESOL Encyclopedia of English Language Teaching (1st Ed.). Published by John Wiley \& Sons, Inc, 1-6. DOI: https://doi. org/10.1002/9781118784235.eelt0208

Krekeler, C. F. (1993). An evaluation of the elementary English-as-a-second language program in Klein, Texas Independent School District (Unpublished Doctoral Dissertation). Texas A\&M University, Texas.

Maftoon, P., Yazdani Moghaddam, M., Golebostan, H., \& Beh-Afarin, S. R. (2010). Privatization of English education in Iran: A feasibility study. The Electronic Journal for English as a Second Language, 13, 1-12.

Marsh, C. (2004). Key concepts for understanding curriculum (3rd Ed.) Routledge Falmer. DOI: https://doi.org/10.4324/9780203326893

Mohamadi, Z. (2013). Program evaluation on general English course: A case study at Tabriz University. Journal of Language Teaching and Research, 4(6), 1285-1297. DOI: https://doi.org/10.4304/jltr.4.6.1285-1297

Moiinvaziri, M. (2014). Students' voice: A needs analysis of university general English course in Iran. GEMA Online® Journal of Language Studies, 14(1), 57-75. DOI: https://doi.org/10.17576/GEMA-2014-1401-05

Mukundum, J., \& Nimehchisalem, V. (2011). An evaluation of English teaching courseware in Malaysia. English Language Teaching 4(3), 142-150. DOI: https://doi.org/10.5539/elt.v4n3p142

Nam, J. M. (2005). Perceptions of Korean college students and teachers about communication-based English instruction: Evaluation of a college EFL curriculum in South Korea (Unpublished doctoral dissertation). The Ohio State University, the USA. http://rave.ohiolink.edu/etdc/view?acc_ num=osu1110161814

Nation, I. S. P., \& Macalister, J. (2010). Language curriculum design. Routledge.

Nation, I. S. P., \& Macalister, J. (Eds.). (2011). Case studies in language curriculum design: Concepts and approaches in action around the world. Routledge.

Nemati, A., (2009). Evaluation of an ESL English course book: A step toward systematic vocabulary evaluation. Journal of Social Sciences, 20(2), 9199. DOI: https://doi.org/10.1080/09718923.2009.11892726

Nichols, B, Shidaker, S., Johnson, G., \& Singer, K (2006). Managing curriculum and assessment. A practitioner's guide. Ohio. 
Nunan, D. (1988). The learner-centered curriculum. Cambridge University Press. DOI: https://doi.org/10.1017/CBO9781139524506

Nunan, D. (2003). The impact of English as a global language on educational policies and practices in the Asia-pacific region. TESOL QUARTERLY, 37(4), 589-613. DOI: https://doi.org/10.2307/3588214

Powell, J. M. (2008). English language learner programs and services: A case study of Nebraska middle schools (Unpublished Doctoral dissertation). University of Nebraska, Lincoln. https://digitalcommons.unl.edu/ dissertations/AAI3315207

Richards, J. C. (1990). The language teaching matrix. Cambridge University Press. DOI: https://doi.org/10.1017/CBO9780511667152

Richards, J. C. (2001). Curriculum development in language teaching. Cambridge: Cambridge University Press. DOI: https://doi.org/10.1017/ CBO9780511667220

Richards, J. C. (2017). Curriculum development in language teaching. Cambridge: Cambridge University Press. DOI: https://doi.org/10.1017/ 9781009024556

Richards, J. C., \& Rodgers, T. S. (2014). Approaches and methods in language teaching. Cambridge University Press.

Richards, J. C., \& Schmidt, R. (2002). Longman dictionary of language teaching and applied linguistics. Longman (Pearson) Education.

Robinson, P. (1991). ESP Today. Prgamon Press.

Seedhouse, P. (1995). Needs analysis and the general English classroom. ELT Journal, 49(1), 59-65. DOI: https://doi.org/10.1093/elt/49.1.59

Soodmand Afshar, H., \& Movassagh, H. (2016). EAP education in Iran: Where does the problem lie? Where are we heading? Journal of English for Academic Purposes, 22, 132-151. DOI: https://doi.org/10.1016/j. jeap.2016.04.002

Tavakoli, M., \& Tavakol, M. (2018). Problematizing EAP education in Iran: A critical ethnographic study of educational, political, and sociocultural roots. Journal of English for Academic Purposes, 28-43. DOI: https:// doi.org/10.1016/j.jeap.2017.12.007

Tomlinson, B., \& Masuhara, H. (2018). The complete guide to the theory and practice of materials development for language learning. John Wiley \& Sons, Inc.

Tunç, F. (2010). Evaluation of an English language teaching program at a public university using CIPP model. (Thesis Submitted to the Graduate 
School of Social Sciences), Middle East Technical University, Ankara, Turkey.

Üstünlüoğlu, E., Akgül-Zazaoğlu, K. F., Keskin, M. N., Sarayköylü, B., \& Akdoğan, G. (2012). Developing a CEF based curriculum: A case study. International Journal of Instruction, 5(1), 115-129.

Wang, L. H. C. (1996). A formative evaluation of the English language program in Fong Shin senior high school, Kaohsiung country, Taiwan (Unpublished Doctoral Dissertation). Florida State University, Florida.

Zohrabi, M. (2005). Trends in ESP \& EGP. The first national ESP/EGP conference. Tehran, Iran.

Zohrabi, M., \& Sabouri, H. (2012). An assessment of strengths and weaknesses of Iranian first year high school English course book using evaluation checklist. English Language and Literature Studies, 2(2), 213-222. DOI: https://doi.org/10.5539/ells.v2n2p89 
